\title{
Exit Tales: How \\ Precarious Workers \\ Navigate Bad Jobs
}

\author{
Jeffrey J. Sallaz'
}

\begin{abstract}
Why do some workers quit undignified "bad jobs," while others persist in them? We know a great deal about how people find employment, along with what they do at work. But we have few studies documenting the lived experience of quitting a bad job. Recent structural transformations, such as the demise of Fordism and the curtailment of welfare, have surely recalibrated the strategies by which precarious individuals navigate the labor market. This article, an ethnography that follows a single cohort of call center employees over nine months, documents four main pathways through which such workers leave versus stay in their jobs. It argues that the emergent class of precarious workers is not homogenous. Gender, race, and age intersect with class to shape how one experiences a given bad job.
\end{abstract}

\section{Keywords}

unemployment, work, poverty, job quality, turnover

\section{Introduction}

Shortly before kickoff of Super Bowl XLVI, several dozen employees took their seats in a call center located in the southwestern United States. Among them that day was twenty-five-year-old Matt, a heavily tattooed and self-described "punk

'School of Sociology, University of Arizona, Tucson, AZ, USA

\section{Corresponding Author:}

Jeffrey J. Sallaz, School of Sociology, University of Arizona, PO Box 210027, Tucson, AZ 8572I-0027, USA.

Email: jeffsallaz@gmail.com 
rocker." Matt had been doing minimum-wage work since high school, before becoming an agent at "CallCo" on its "ShipIt" account. ${ }^{1}$ Several months in, he remained satisfied with the $\$ 11$ hourly wage, which he described as "real decent." However, Matt found the task of "deescalating irates" all day long to be emotionally draining. On this given Sunday, Matt himself was in an irate mood. He had requested the day off over a month ago, in case his favorite team made the Super Bowl. It had, but he was nonetheless scheduled to work.

Three hours into the shift (and twenty minutes after kickoff), Matt's coworkers, of which I was one, received an online message. We were now short an agent for the day. Rumors quickly circulated that Matt had faked an illness in order to be sent home (or, more likely, to the nearest sports bar). Eyewitness accounts soon emerged to set things straight. Matt had been "termed" (terminated) for committing a cardinal sin of the call center. During a troublesome interaction with an irate, he'd hit his phone's mute button and mumbled, "ungrateful cunt." But the mute button had not been depressed, and the caller had immediately phoned back to report the indiscretion.

A few feet from Matt's now-empty cubicle sat sixty-one-year-old Susie, who landed in call center work after her marriage failed and her small business went under. After only a few months on the phone, she was a master of the mute button. As her right hand tapped at her keyboard, her left hand repeatedly alighted upon her phone's base unit, allowing her to carry on two dialogues simultaneously. Mute off: "Yes sir, I do apologize, your package will be reattempted tomorrow." Mute on: "Cranky bastard, what more do you want from me?" On our fifteen-minute breaks, Susie hurries to the smoking patio for several quick huffs. To deal with the resulting cough, she keeps in her purse a value-pack of store-brand cough syrup. On a typical shift, this ethnographer estimates, Susie imbibes two to three bottles in their entirety.

Matt and Susie were two of twenty-one precarious workers whom I tracked for nine months in 2011-2012. They were precarious in that they lacked wealth (savings), human capital (college degrees), and were living lives on the edge of hardship (Standing 2014). Yet they also remained committed to hard work as a means to achieve a secure and dignified "good job" (Kalleberg 2013). CallCo targeted precisely such people. Plastered on bus stops throughout this Sun Belt city were its job advertisements, depicting a diverse set of workers in professional dress and seated comfortably at desks. In reality, however, outsourced call centers are prototypical "bad jobs." Eleven dollars an hour doing stressful call-work is the first and only rung on CallCo's job ladder.

Here something unexpected happened: workers' strategies for navigating this bad job diverged. Some, such as Matt, trudged along before rebelling in dramatic exits, while others found new jobs and quietly resigned. Then there were 
those who stayed. These included older workers such as Susie, who resigned themselves to coping until they could retire, and single mothers who rationalized their situation through a narrative of self-sacrifice. I identified these four trajectories via an abductive methodology. The resulting typology shows that precarious workers deploy multiple strategies for navigating a bad job - and that gender, age, and race intersect to shape their opportunities to do so.

\section{The Leaving Process}

In the fall of 2011, I commenced an ethnographic study of an outsourced call center's labor process. ${ }^{2}$ From the start, however, I was struck by how frequently workers opted out of this labor process. Annual attrition at CallCo was more than 100 percent, while thirteen of the twenty-one workers whom I followed exited within six months of being hired. This was puzzling to me. Call center work is notoriously stressful (Bain and Taylor 2000), but the pay at CallCo is good relative to alternatives in the local labor market. Plus, this was in the aftermath of the 2008 financial collapse, and all of these workers were in tough financial straits. Here I ran up against a theoretical asymmetry. The literature is replete with studies of the labor process, yet it lacks a commensurate understanding of the leaving process.

I thus set up a research agenda to explain why some, but not other, precarious workers quit this (relatively) well-paying bad job. My analytical approach was not deductive, in the sense of explicitly testing extant theory, but nor was it purely inductive, for I was not building theory de novo. Rather, my approach was abductive. The essence of abductive reasoning, when applied to qualitative data, is "a creative inferential process . . . based on surprising research evidence" (Timmermans and Tavory 2012, 167). Initial immersion in the empirical lifeworlds of one's subjects invariably leads to puzzling discoveries (Ong 2012; Maanen, Sørensen, and Mitchell 2007). The researcher then, as fieldwork progresses, engages with the literature in a focused and creative manner, so as to "shape a conceptual apparatus that makes sense of . . . puzzles arising in the field" (Watson and Watson 2012, 685, italics mine). To explain the puzzling of leaving patterns at CallCo, I fashioned three novel abductive concepts - navigation strategies, biographical trajectories, and material embeddedness - from workplace ethnographies, theories of postFordism, and the literature on the end of welfare in America.

\section{Navigation Strategies}

What do we know about decisions to leave versus persist in problematic work situations? How does one strategically navigate a bad job in situ? To 
survey what prior research has had to say about such questions, I consulted the Workplace Ethnography Project (WEP), a publicly available database indexing all 158 workplace ethnographic monographs published between 1940 and 2007 (Hodson 2001). ${ }^{3}$ Of these, 122 describe episodes in which the ethnographer witnessed an employee quitting, contemplating quitting, or being fired. Because the WEP catalogues each such exit-episode by page number, I could readily locate it and then read enough contextual material to get a sense of what was going on in that particular situation for that particular worker. I found that the WEP distinguished between two main navigation strategies, and that these captured differences among the exits I was witnessing at CallCo.

On one hand are what I call cathartic exits. These are unpremeditated departures that relieve some underlying tension for the worker. Cathartic exits are typically precipitated by an identifiable event that is experienced as an epiphany, after which the worker quits or is fired. Consider Fink's (1998, 142) recounting of the exit of Fred, a meatpacker:

While waiting to talk to a nurse, he stepped out into the hall for a smoke. The nurse stormed out and accused him of coming to the dispensary to catch a smoke. She ordered him back to work. Fred said she treated him like a kid, and he lost his temper, yelled, and quit his job.

Reading accounts such as this one, I was able to make sense of Matt's exit from CallCo as a cathartic experience. Although Fink did not track Fred down on the night of his exit, I did Matt on his. He had spent the morning (and previous evening) fuming that the company had not honored his request to have Superbowl Sunday off. Sitting on his barstool that night, he voiced no regrets and in fact seemed relieved to be done at CallCo. In my fieldnotes I noted his contentment, but also my own concern as to how he would pay his bills from this point on.

Exits such as Matt's, while cathartic, entail risk insofar as they are spontaneous and so render the worker unemployed. In contrast are calculated exits. The WEP describes these as episodes in which a worker leaves but with a firm plan in place. He or she may have another job lined up, or may plan to enter spheres of domesticity, entrepreneurship, or retirement. Milkman (1997), for instance, documented how autoworkers strategically accepted an early retirement offer in order to start small businesses. And Newman (2000, 20) described a fast-food worker, Carmen, for whom "children had a lot to do with [her] decision one day to leave Burger Barn ... she walked out of the job and set about becoming a housewife." For such workers, exits are less an immediate catharsis than a calculated gamble. 
The WEP provided an important concept - that of navigation strategiesto classify the exits I was observing at CallCo. But this literature had its limitations. First, nearly all of the ethnographies in the database focus on the labor process and so mention the leaving process but in passing. They rarely contextualize individual exits, nor do they systematically compare workers who leave to those who stay on the job. Second, the majority of workplace ethnographies were researched during the 1980s or earlier. This was prior to two major transformations of the American economy: the erosion of Fordism and the end of welfare. Both have likely changed the way in which workers navigate problematic work environments. Drawing on the literatures documenting these transformations, I generated two further abductive concepts.

\section{Biographical Trajectories}

Like many contemporary bad jobs, CallCo masquerades as a good one. It recruits workers by hinting at the American Dream, in which firms reward hard work with good pay, benefits, dignified working conditions, and a secure career. In reality, this arrangement, commonly dubbed Fordism, deteriorated during the final decades of the twentieth century. Globalization, financialization, and neoliberalism force firms to minimize costs and maximize flexibility. While a small number of educated professionals retain "good jobs," the majority find themselves stuck in "bad jobs" characterized by stagnant pay, stressful working conditions, and a lack of job security (Pedulla 2013; Kalleberg 2013; Mears and Finlay 2005). The Fordist working class is now a post-Fordist precariat.

As the precarious individuals who became CallCo agents came to realize that they had not found a good job, their strategies for navigating their predicament diverged. Some exited cathartically, some calculated exits, while others stuck it out. To explain such divergence, I contextualized how this particular "bad job" fit within each worker's prior life experiences. I call this abductive concept one's biographical trajectory, that is, the length and vector of one's journey through the shifting landscape of jobs in America.

From the start, I noticed that patterns of leaving versus staying at CallCo were correlated with age, gender, and race. The concept of biographical trajectory suggested explanations for such patterns. The literature, for instance, documents that young Americans cling tenaciously to the American Dream, even as chances of obtaining it diminish (Silva 2012; Putnam 2015). Older workers in turn, having experienced Fordist prosperity firsthand, may struggle to adapt to post-Fordist precarity (Sharone 2013; Abramson 2015). Others have argued that women and nonwhite workers have unique experiences of the post-Fordist economy. The implicit model underlying the Fordist system 
was that of a white male breadwinner; the end of this system may have in some respects opened up new opportunities for minorities and women (Smith 2005; Piore and Safford 2006; Pager and Shepherd 2008). Differences within the class of precarious workers are further suggested by the literature on changing welfare policies in the United States.

\section{Material Embeddedness}

At the same time that good jobs were disappearing, the American government essentially ended welfare. The Personal Responsibility and Work Opportunity Act of 1996 put strict time and eligibility limits on material benefits for the unemployed. The underlying logic of the policy is to foster labor market participation by materially supporting only those poor Americans who are working (Wright 2012). This occurs mainly through the Earned Income Tax Credit (EITC), which lowers the income tax paid by low-wage workers and thus boosts their net earnings. As has been shown, however, the benefits of the EITC are received only annually (i.e., on tax day) and in sums that are difficult to predict in advance (Halpern-Meekin et al. 2015). In line with this research, none of my subjects referenced welfare or any other form of governmental support as available to them in the event of unemployment.

It is reasonable to assume that the end of welfare has altered precarious Americans' strategies for navigating bad jobs. If one can anticipate material assistance from the state when unemployed, as in the previous welfare regime, one should feel secure to quit a bad job - or even to remain out of the labor market entirely. This is true even if one has few other resources and significant obligations, as Edin and Lein (1997) demonstrated in a classic study of poor single mothers. Taking into account the costs of transportation and child care, it was strategic for such women to stay on welfare rather than toil in minimum-wage jobs.

In post-welfare America, the stakes are different. Falling into unemployment now entails not gaining access to state support, but losing it insofar one is ineligible for the EITC. Many have argued that this has essentially chained workers to bad jobs, and especially workers such as single parents who are obligated to provide for others (e.g., Collins and Mayer 2010). Others have conducted case studies of precarious individuals, revealing how they mobilize resources from arenas such as friendship networks, family ties, and subcultures to survive outside of the labor market (Venkatesh 2009; Desmond 2012; Woodward 2013). As my fieldwork progressed, it became clear that my coworkers' strategies for navigating their CallCo jobs depended not only upon their past work histories, but upon their stock of resources and 
Table I. Conceptual Apparatus for Studying Exits.

\begin{tabular}{|c|c|c|}
\hline Abductive Concept & Focuses Attention Upon & Derived from Literature \\
\hline Navigation strategy & $\begin{array}{l}\text { The lived experience of work } \\
\text { and the process of deliberating } \\
\text { an exit }\end{array}$ & $\begin{array}{l}\text { Of all workplace } \\
\text { ethnographies published } \\
\text { prior to } 2007\end{array}$ \\
\hline $\begin{array}{l}\text { Biographical } \\
\text { trajectory }\end{array}$ & $\begin{array}{l}\text { The worker's employment } \\
\text { history, conceived of as a } \\
\text { vector through the emergent } \\
\text { landscape of bad jobs }\end{array}$ & $\begin{array}{l}\text { On post-Fordism and the } \\
\text { new economy of bad } \\
\text { jobs }\end{array}$ \\
\hline $\begin{array}{l}\text { Material } \\
\text { embeddedness }\end{array}$ & $\begin{array}{l}\text { The totality of an individual's } \\
\text { material resources and } \\
\text { obligations }\end{array}$ & $\begin{array}{l}\text { On decision making in } \\
\text { postwelfare America }\end{array}$ \\
\hline
\end{tabular}

obligations. I label this their material embeddedness, my third abductive concept for studying exits (Table 1).

\section{Studying Exits Ethnographically}

The conceptual apparatus that I assembled to explain the leaving process at CallCo also explained why empirical studies documenting exits in situ are rare. When cathartic, exits are unplanned and spontaneous experiences; when calculated, they are often concealed until the final moment. Recent macrolevel economic changes - that is, the demise of Fordism and the end of welfare - should have made exits even rarer. A nine-month participant observation study of call center work, I realized, was a unique opportunity to study exits ethnographically.

How do researchers document regular yet unpredictable events from the point of view of participants themselves? One established approach is to embed oneself in a group known to be at risk for the event of interest. When it does occur, there is a reasonable chance that the researcher may witness it firsthand. If not, one is positioned to follow up with various participants and witnesses so as to build a "thick-enough description" of the event (Cromdal, Osvaldsson, and Persson-Thunqvist 2008, 927). This approach has been used recently by Desmond (2012), who moved into a trailer park in order to study evictions, and Goffman (2009), whose multiyear residence in an urban neighborhood allowed her to document episodes of police brutality toward African Americans.

A senior manager at CallCo granted me permission to join a cohort of twenty-one CallCo new-hires. Although diverse in terms of gender (eight men and thirteen women), race/ethnicity (ten identified as "white" and eleven 
as "nonwhite," primarily Latino), and age (ranging from twenty to sixtythree), they all had one thing in common: they were precarious workers in a Sunbelt city that had been hit hard by the recession of 2008. All hailed from working-class families, with typical parental occupations including mechanic, soldier, Wal-Mart worker, gardener, and housewife. All had finished high school, though only one of the twenty-one had a postsecondary degree. All reported living "month to month," none had any accumulated wealth, and most had significant debt, such as large credit card balances and "upsidedown" mortgages.

My research was for the most part overt, in that I informed my coworkers ("teammates") and immediate supervisor ("team leader") of my status as a researcher on the first day of our month-long training course. But otherwise, I did all that I could to make sure that I was perceived and treated as a regular CallCo agent. I received an official employee ID card and, after our training program, was expected to work full-time on the production floor and to meet all of the firm's metrics regarding speed, quality, and punctuality. In addition, the thousands of callers with whom I interacted assumed that I was a regular employee - and took out their frustrations on me accordingly.

Participant observation (PO) helped me to understand the daily stress and indignities that come with working in an outsourced call center. It also allowed me to establish a basic rapport with each of my twenty-one teammates. Training entailed frequent interactions and "team-building" exercises; on the production floor, team members were seated in the same area and took their breaks and lunches together; and I carpooled to and from work with several of my coworkers. PO, nonetheless, had its limits, in that many of the things that my abductive concepts required knowing about my teammatessuch as their employment histories, future plans, and other sources of financial support and obligations-were not topics that emerged organically during everyday conversations. To collect such information, I supplemented PO with semistructured interviews. These took about an hour on average and were conducted outside of the workplace. Respondents were assured that their identities would be kept anonymous.

A common narrative arose from PO and interviews. My teammates had at first been optimistic that they had found a good job. Call center work paid well - eleven dollars per hour, a 52 percent premium above the minimumwage - and did not require manual labor. But this hope was soon dashed. By all measures, job quality at CallCo is low: the work is Taylorized, undignified, and lacks an internal job ladder. Here was a natural experiment of the leaving process. How would these twenty-one precarious workers manage the push (stressful work) and pull (high pay) of call center work? Who would stay and who would go? 


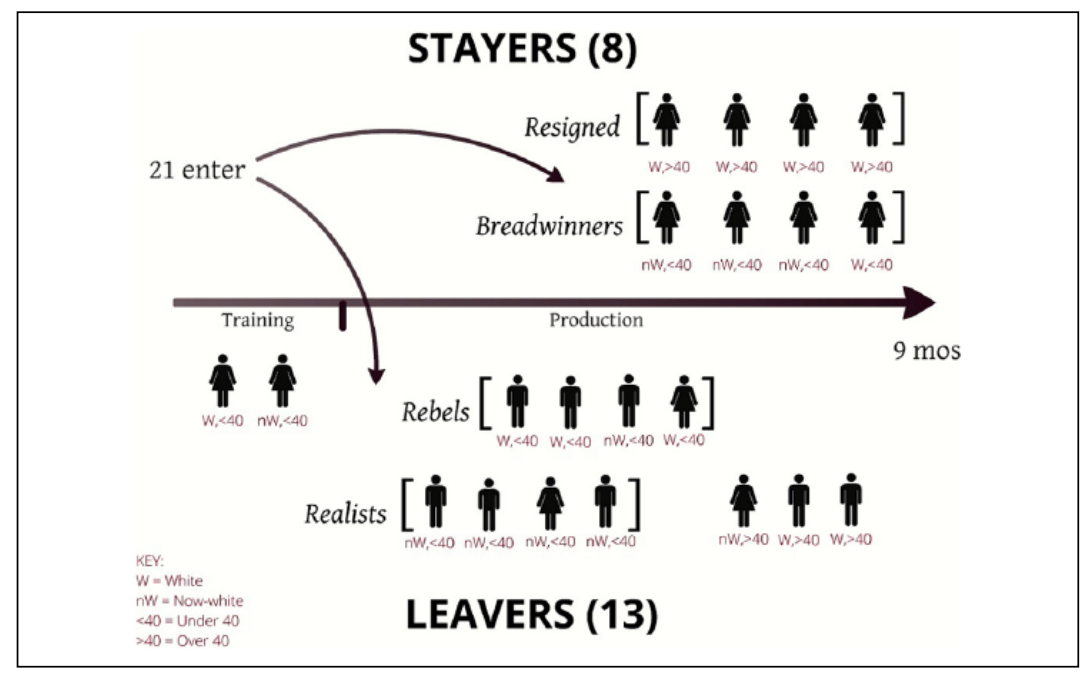

Figure I. Trajectories of staying and leaving.

\section{Four Paths through a Bad Job}

Figure 1, below, is a timeline differentiating eight "stayers" who persisted at CallCo for at least nine months, from thirteen "leavers." Using the abductive concepts outlined above, I propose four categories to capture most of these trajectories. ${ }^{4}$ Leavers were mostly either young rebels who repeatedly violated the rules of the workplace, or realist providers who calculated moves into new jobs. Meanwhile, young female breadwinners found themselves tethered to this bad job, as did downwardly mobile older women who resigned themselves to their predicament.

\section{The Rebels}

Matt (the worker described in the opening anecdote), Ben, Jill, and Eddie were twenty-somethings mired in minimum-wage work yet aspiring to upward mobility. They had leapt at the chance to earn $\$ 11$ per hour, and initially believed that CallCo was a stepping stone into the world of good jobs. But they were immediately troubled by call center work. While each attempted to acclimate to the job, their struggles were futile as they experienced distress that in turn led to disciplinary infractions. Eventually, all four tired of the fight and indulged cathartic exits. Although they did not line up other work in advance, these workers had few material obligations and were 
able to reorganize their personal lives so as to buffer a fall into unemployment. Because their tenures at CallCo were marked by constant turmoil, I label these leavers Rebels.

All four of these workers had graduated from local high schools and were embedded in youth subcultures. Matt had tattoo "sleeves" and sang in a local band; Ben identified as a "hipster" and spent his free time playing online video games; Jill dressed in Grateful Dead T-shirts and spoke openly of her regular marijuana use; while Eddie, the only nonwhite (Latino) worker in this group, had spiked black hair and was a devotee of "metal" music. After high school, each had enrolled at local community colleges. But, as first-generation students, they struggled with their grades and with paying tuition fees, and all dropped out before obtaining a degree. Jill's succinct narrative captures well these workers' experiences with post-secondary education:

I left [college] because, at that time, I had no idea what I wanted to do. I didn't wanna waste money trying to figure out what I wanted to do. So I just left.

Despite not finishing college, the Rebels took pride in their work ethic and believed that they would eventually be rewarded with good jobs. Each had been working since the age of sixteen or seventeen. Immediately prior to starting at CallCo, Matt had been employed in a hardware store, Ben as a pizza deliveryman, Jill as a clerk in a "head-shop," and Eddie as a doorman at a music club. Like the brand devotees described by Williams and Connell (2010), they had settled into minimum-wage jobs that accommodated their subcultural lifestyles. As they entered their twenties, however, each began falling behind on expenses such as rent, car payments, and credit card bills. The Rebels were easily seduced by CallCo's promise of a good job in a whitecollar setting. As Eddie recalled thinking, "I couldn't believe I was gonna have my own desk. My own seat, my own workspace, my own area. It was an actual desk job!"

Upon finishing training and entering production, however, the Rebels found that their hopes had been misplaced. Eddie realized that the job consisted of "getting yelled at eight hours a day," while Jill recounted that "within the first week, I told myself, this is horrible, this is being treated like shit." Nonetheless, all four workers made sincere efforts to adjust to the job. For Matt, the punk rocker, this was part of a larger personal project to "grow up and stop acting like a fucking kid." Hipster Ben explained:

I didn't just quit immediately. I was there for something like six weeks after training. ... I tried. ... I was living with my girlfriend and we had a nice little 
house and then we-I- - had to pay rent and utilities and everything. And I didn't quit at first because it was just irresponsible to quit.

So dedicated were they to the Fordist ideal of effort and perseverance eventually being rewarded with a good job, these workers attributed their dissatisfaction at work to their own personal failings and attempted to soldier on. In my fieldnotes, I noted how the resulting stress seemed to manifest itself physically for these workers. Eddie, with whom I carpooled to work, complained each morning of insomnia and nightmares. For Jill it was a flaring up of her chronic pain disorder, and for Ben constant headaches and an omnipresent sense of "dread." Matt reported an undesired increase in his alcohol use, and as the weeks progressed began smoking marijuana in the parking lot during our lunch break.

It did not take long for these workers' inner struggles to manifest themselves as acts of rebellion. Call centers are replete with rules, and the Rebels began breaking them regularly. Matt's infraction, of insulting a caller, was the most dramatic. The other Rebels rapidly accumulated disciplinary "points" for minor infractions such as surfing the Internet, texting while handling calls, returning tardy from break, and calling off work. Jill described her daily struggle to get out of bed and drive to CallCo thusly:

Like I would just ask myself, can I call in [i.e., report an unexcused absence]? Just kind of calculate my points in my head, see if I could, just like, wanting to be anywhere in the world but there.

Jill referred to "calculating" her points because upon reaching twelve infractions, a CallCo worker is automatically terminated. In fact, upon reaching eleven points, workers are required to sit down for a "coaching session" with a manager who warns them that they are one misstep away from being fired. While CallCo intends these sessions as, in the words of one manager, "wake-up calls," they had a curious effect. Workers did experience them as epiphanies, but not in the way the firm intended. Convinced that they would soon be fired ("kicked out the door," in Jill's words), the Rebels recast leaving CallCo as the only responsible thing to do. Ben and Eddie "called in" on the days following their coaching sessions to resign, while Jill overslept on hers and missed work. She phoned our team leader, but admitted in our interview that she had technically been terminated. Taken as a whole, the Rebels' exits show how blurry, in practice, is the distinction between "voluntary" and "involuntary" attrition. It was as if, to paraphrase Katz $(1988,7)$, they had empowered their employer to seduce them to leave. 


\section{Realists}

Caleb, Jerome, Tony, and Camila resembled the Rebels. These twenty-somethings had strong subcultural identities and were embedded in local networks of family and friends. They too had pursued call center employment as a mobility strategy, up and out of minimum-wage work. And these workers too found call-work to be stressful and undignified, and so exited within the first few months. But there was a key distinction between these two groups of leavers. All four of the Realists provided for dependents-young childrenand so had to navigate their exits differently. Rather than rebel and indulge cathartic exits, this group of workers, whom I call Realists, furtively lined up other employment in advance. As pragmatic providers, these workers had to make calculated exits.

All four Realists were young parents co-providing for dependents. Caleb and his fiancée were expecting their second child, Jerome and his live-in girlfriend had just had their first, Tony shared custody of his daughter with his ex-girlfriend, while Camila and her husband had two children. Being a good provider was important to these workers, and all reported taking their obligations into account when making decisions generally. As Caleb explained,

I turned twenty-four a couple of weeks ago. I'm still young but I don't feel that way. [Why not?] Cuz I'm about to have a newborn and a two-year-old. Everything I do, I gotta think of them. It ain't just about me.

In line with such sentiments, Caleb and the other Realists had compiled extensive work histories. All four had finished high school but failed to complete postsecondary programs. Having children while young had only intensified the imperative to earn wage income immediately rather than take on debt to pay for college.

The Realists, however, had become stuck in minimum-wage food-service positions, and desperately sought jobs that paid better and provided more dignity. Consider Caleb and Jerome, African Americans whose families had migrated to this Sunbelt city when they were children. Both had been working at fast food establishments since high school— jobs that they despised and quit immediately upon being hired at CallCo. As Jerome told me on our second day of training:

I'm [here] cuz like, I was doing the fast-food thing. And by the word fast-food, you already know how it is. You get treated like garbage and you work like a dog. I thought [of] the people who's doing call centers compared to work in fast food: they make so much money but they don't have to move anywhere. They just sit and talk over the phone. 
Camila and Tony, both Latino, also initially viewed call center work as an entry portal into the world of good white collar jobs. But they continued to work nights at their existing jobs-Camila as a stocker in a grocery store, Tony as a cook at a Chinese restaurant - even after being hired at CallCo. Like the Rebels, the Realists all reported the $\$ 11$ hourly wage to be the highest they'd ever earned.

The Realists' quick exits came as a surprise to everyone, including me. Relative to my other teammates, I noted during my fieldwork, they complained much less about the work and did not accumulate disciplinary points. In fact, they seemed like model employees. Camila, for instance, was named CallCo's Employee of the Month after our first month on the production floor, in recognition of her perfect attendance and low handle time. This, all agreed, was a remarkable achievement for a "newbie"! Yet the day after receiving her award, Camila phoned in to resign from CallCo. Over the following six weeks, Tony, Caleb, and Jerome also resigned - all with little drama or fanfare.

What was going on with these workers behind the scenes? Here, interviewing revealed dynamics that participant observation could not: namely, that the Realists had begun seeking alternative work arrangements shortly after joining the production floor. They recounted quickly coming to realize that they had misjudged just how mentally and emotionally taxing phonework would be. As Caleb described it, "You start to feel so wrong when you walk in that door, and you felt so brain-dead when you walked out each night." Tony, who quickly mastered CallCo's computer system, complained of "stiffness and boredom" as his first weeks in the call center went by, while Camila said simply that it had been the "most mind-draining job ever."

The Rebels had attributed their discontent to their own personal failings, in particular their immaturity. But not the Realists. In our interviews, they did not describe feeling guilt or a sense of personal failure upon realizing that call center was not what they had hoped. They accepted their unhappiness as a fact, took stock of their options, and calculated a path out of their predicament.

Camila, for instance, had been aggressively negotiating a wage increase with her manager at the grocery store. When she'd showed him her Employee of the Month plaque, he'd finally been convinced that she might resign and so agreed to a dollar per hour pay raise. Tony also used his CallCo position as bargaining power, by procuring a promotion at the Chinese restaurant, from line cook to shift manager. Both Jerome and Caleb, meanwhile, had long aspired to work in the retail sector, especially in stores selling goods that they themselves wore and identified with. They had begun submitting applications all over town as soon as they could put "customer service representative" on 
their résumés. Although all of the Realists ended up moving into positions paying less than $\$ 11$ per hour, none regretted leaving CallCo. They were marginally better off than they'd been before, and they felt less stressed in their daily lives.

\section{Breadwinners}

Consider now my eight teammates who, nine months after the date of hire, remained on the job. As with those who exited, stayers were not of a stripe. Four of these workers I have labeled Breadwinners. Alma, Laura, and Sofia were young Latina women and never-married mothers; Ashley was white and the lone caregiver for her infirm mother. Prior to applying at CallCo, they had been working minimum-wage jobs (as a house cleaner, pharmacy cashier, fast-food worker, and retail worker, respectively) and struggling, as sole providers, to stay above the official poverty line. While the CallCo wage granted these workers breathing room financially, it took time for the Breadwinners to hone a narrative of self-sacrifice that allowed them to cope with the job.

As with the other categories of workers, it did not take the Breadwinners long to realize that CallCo did not offer truly good jobs. After just a few days on the production floor, they began to voice dissatisfaction with various aspects of the work, from the incessant barrage of calls to the tedium of having to apologize to irates. In the breakroom, for instance, Sofia assessed her new job as follows: "You're there eight hours a day and every single call is a complaint. None of the calls are actually happy, you know. I mean, out of 150 calls you might get like one or two people who are excited to talk to you." Ashley, seated across the table, concurred: "It's more or less that all calls are bad. I don't mean just like 'you guys suck' sort of thing. They're like cussing, swearing, giving you death threats."

On the other hand, these workers believed that an $\$ 11$ hourly wage was the most they could aspire to given the local labor market. Alma, in our interview, was adamant on this point: "Yah, I think [the pay] is fair. What more am I going to get out there right now?"

Whereas the Realists had weighed the calculus of "bad job" versus "good pay" and opted to move back into lower-paying work, the Breadwinners made the opposite choice. Although both groups were working to support dependents, the Breadwinners were sole wage-earners in their households. Laura and Sofia reported having minimal to no contact with the fathers of their children. Alma, who had three children from two different men, received financial support from one of the fathers, but it was modest and intermittent. Ashley lived alone with her mother and was vague about the whereabouts of her father, but she was clear that they could not count on any support from 
him. Alma's summation of her situation exemplifies well the plight of these four young women: "I do have to solely rely on my CallCo money and it's hard because, I mean, I'm a single mama of three kids and my youngest is a baby."

As sole providers themselves reliant solely on wage income, the Breadwinners were especially sensitive to how much of a difference a few dollars per hour makes. When the income of a single wage earner constitutes the entirety of total household income, the gap between the $\$ 7.25$ minimum wage and CallCo's $\$ 11.00$ wage is significant. For a full-time worker, the latter translates into an extra $\$ 600$ of gross monthly income, which can cover multiple trips to the grocery store or, as in Laura's case, rent in a "nice area":

If I didn't have this employment right now, I think I would be "that mother." We'd be impoverished, and living back in that not-so-nice area. I would be, you know [voice trails off]. Let's just say my children wouldn't have what they have right now.

By the time I conducted formal interviews with these four workers approximately nine months after they had started working at CallCo, they had converged upon a unitary narrative as to why they had stuck with the job. Quite simply, they were doing so for the sake of others who depend on them. As Ashley explained,

My mom and dad lived together, but since my dad left, I was the one who was gonna support us. And this is supporting us. We're renting a little one-bedroom apartment and we literally have 150 bucks left after all our bills just for groceries. It's the money that's keeping me [at CallCo].

Sophia's explanation made the same point concisely:

Without no child support I know what I have to do. I gotta get there [i.e., CallCo] on time and do my job or else I'll see my children suffering.

Being a Breadwinner, in sum, served as a potent motivation and rationale for coping with a well-paying bad job. At the end of my study period, none of these four women were actively looking for other work.

\section{The Resigned}

The final category of workers consists of Susie, Deb, Gail, and Candy, whom I have labeled the Resigned. These were women in their late fifties and early sixties who had once achieved the American dream, only to then experience 
steep downward mobility. Call center work was a way to halt their descents. Like their teammates, none of these workers initially found much dignity in their work. Susie, for instance, soon came up with a running joke to describe our opening pitch on the phones: "Thank you for calling, how would you like to abuse me today?" Yet rather than resign from the job, these four workers resigned themselves to it. CallCo offered a means to support themselves until they became eligible for state retirement benefits; in the meantime, they developed idiosyncratic coping strategies.

"If I didn't work, I wouldn't be living at all. And at sixty-three I didn't expect this, that I'd still be working." So summarized Candy her current lot in life. This was a trajectory - of being cast unexpectedly, late in life, into the precariat - that defined the Resigned. All four women had children soon after finishing high school, yet managed to balance family and careers in the following decades. These were remembered fondly today as periods of security and upward mobility. Deb and Gail married men with stable blue-collar jobs, while they themselves worked as a school counselor and an HR rep, respectively. Candy divorced and remarried several times, but maintained steady income as a real estate agent. Even Susie, who lived with her daughter and mother during her twenties and thirties, recalled no problems finding fulltime (typically clerical) work that paid well.

After their children left home, all four women left the labor market to pursue long-standing dreams of becoming entrepreneurs. Susie, an avid reader, opened a secondhand bookstore; Candy became a building contractor; Gail started an embroidery business; and Deb opened a small bakery. That they had been able in the decades previous to simultaneously raise children and accumulate capital for their business ventures attests to the prosperity that was possible for the working class under Fordism. Their subsequent experiences illustrate how unprepared they were for post-Fordism.

The early 2000s confronted the four women with multiple personal financial crises. Around this time, each lost access to supplemental family income. Deb and Gail divorced, Candy's husband lost his job, while Susie's mother retired. All of their small businesses were swallowed up as well. The housing bust ended Candy's construction venture, while the resulting recession dried up demand for the other women's brick-and-mortar retail shops. Awash in debt and with bills to pay, the women, after multiyear absences, ventured back into the labor market. The resulting job search humbled them, and call center work quickly emerged as the best chance to cling to some semblance of a good white-collar job.

"Nobody was hiring," Deb recalled of 2009, "that was the ugly year." Compounding the reality of a tight labor market in the aftermath of a financial crisis, the women experienced age discrimination from potential 
employers. "I had several tell me you can't have the job because you're too old. And so, that was interesting. I never thought of that," recounted Candy. Gail recalled coming to realize that "the older you get, the less people want you." Retail, personal services, and other jobs implicitly requiring "good looks" were ruled out, and the women began to consider their other options. Gail specifically mentioned being horrified at the thought of walking into a Taco Bell (a Mexican-themed fast-food franchise) and asking for an application, while Susie remembered mastering her fear of needles should she have to begin selling her plasma.

With such scenarios looming, the women adjusted their aspirations accordingly. Now, a desk job - any desk job - came to seem eminently desirable. CallCo, in this context, offered one last chance to halt their downward trajectories. In addition to the wage premium, call center work retains a patina of white-collar status as agents wear business-casual attire (not uniforms), sit in desk chairs (rather than stand at a register), and work in an air-conditioned office. But then reality hits: the Taylorized work routines, the finicky computer system, the irate callers. As Candy, in our interview, recounted,

I wasn't looking for a call center. None of us were. None of us thought we'd be here. And at first I really struggled. It took me a while. I was not a happy camper for about a month.

What the Resigned workers initially lacked were means by which to cope with the daily stress and indignity that call center work entails. Certainly the minor tactics that agents learn on the production floor-such as venting via the mute button, or even sipping on cough syrup-helped. But unlike the Breadwinners, the Resigned did not converge upon a single narrative as to why they persisted at CallCo. Candy, for instance, described how she overcame her initial struggles by coming to see the job as a learning opportunity:

[How are you feeling now? It's been almost a year.] Now? I'm not negative about this at all. I'm being paid to learn things that I never could when I was young. It's a blessing, really it is.

Gail in turn spoke of having to absorb abuse from irate callers as a penance ("payback") for all the times in her life that she'd been rude to customer service agents:

It's kinda like payback for me because I used to be the customer that would be rude. . . . Now I'm on the other end. I found out in my life that I always get to 
live on both sides of the fence and experience both sides and this is my opportunity right now.

Although the coping narratives of the Resigned diverged from those of the Breadwinners, both groups seemed to deploy what Bourdieu $(2000,142)$ calls amor fati, or the semi-conscious work of transforming necessities into virtues. Like the Breadwinners, none of the Resigned were looking for other jobs at the time of our final interview. They planned to persist until they reached retirement age and could claim income and health insurance from the federal government.

\section{Discussion}

The simultaneous demise of Fordism and welfare represented a double-punch for America's working class. In decades prior, a worker lacking a college degree could still obtain a good job-and count on material assistance from the state should one fail to materialize. Today, in contrast, a growing number of workers find themselves "trapped in precarious employment" (Tomlinson and Walker 2012, 55). With "both hands tied" (Collins and Mayer 2010, 1), they have "no way out" (Boushey 2005, 659) of this barren landscape of bad jobs. Denied agency and strategy, the precariat can but endure.

Such imagery suffuses the literature on America's working poor, but it did not do justice to what I documented during my ethnography of a prototypical bad job. The twenty-one precarious workers who accepted positions as outsourced call agents deployed a variety of strategies for navigating their situations. To make sense of these patterns, I reasoned abductively and collected extensive data on each individual through participant observation and interviewing. In this discussion, I elaborate two broad conclusions from my study. First, from the point of view of precarious workers themselves, the emergent landscape of bad jobs is highly differentiated. Second, the precariat is a heterogeneous class; their navigation strategies vary according to their biographical trajectories and material embeddedness. Both of these findings speak to how class intersects with gender, race, and age across America's post-Fordist labor market.

\section{A Differentiated Landscape}

My twenty-one teammates would all have been classified as members of the emergent precariat class. They had no savings and minimal human capital. Prior to becoming CallCo agents they had been either unemployed or working minimum-wage jobs. Each nonetheless clung to the American Dream, 


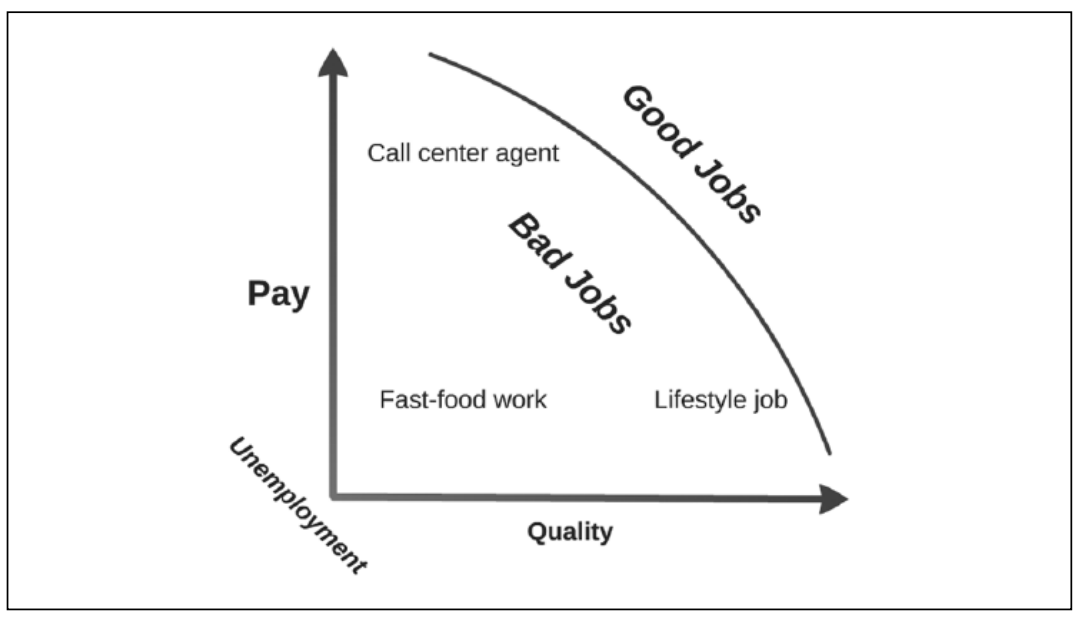

Figure 2. Participant mapping of U.S. labor market (i.e., the bad job space).

and each entered CallCo hopeful that they'd landed a good job. But they were mistaken. In the weeks and months to come, they figured out that, rather than a stepping stone into the world of good jobs, CallCo was a heretofore undiscovered species of bad job. As a firsthand witness to such reckoning, I could see that workers were operating with a shared, if implicit, mental mapping of the contemporary labor market. Figure 2 is an attempt to represent this folk classification system in a two-dimensional space.

The vertical axis in Figure 2 represents a job's wage, and the horizontal axis its quality. When my coworkers articulated the type of work that they ultimately aspired to - the "good jobs" that they hoped were "out there"they described positions paying substantially more than the minimum wage and offering autonomy and dignity. With the exception of the downwardly mobile Resigned workers, however, none had ever held such a good job. But it was clear that their prior experiences had led them to differentiate between various species of bad jobs.

The least desirable jobs - the baddest of the bad, so to speak - were those that paid the minimum wage and offered minimal autonomy and dignity. Fast-food work, in which one is, in the Realist Jerome's words, "treated like garbage," exemplifies this species of job, depicted in the lower left quadrant of Figure 2. Then there are jobs that, though they pay the minimum wage, are less routinized and allow workers to express their identities (these appear in the lower right). Retail or personal service jobs, in which one is hired because one embodies a certain "lifestyle" resonant with a particular company or 
Table 2. Categories Compared.

\begin{tabular}{|c|c|c|c|c|}
\hline & Sex & Race & Age & Navigation Strategy \\
\hline \multicolumn{5}{|l|}{ Leavers } \\
\hline Rebels & M & White & $<40$ & Cathartic exit \\
\hline Realists & M & Nonwhite & $<40$ & Calculated exit \\
\hline \multicolumn{5}{|l|}{ Stayers } \\
\hline Breadwinners & $\mathrm{F}$ & Nonwhite & $<40$ & Coping to provide \\
\hline Resigned & $\mathrm{F}$ & White & $>40$ & Coping until retirement \\
\hline
\end{tabular}

brand, exemplifies this sort of work (Williams and Connell 2010). Call centers, in this schema, represent a third species: a well-paid bad job. Though it offered several dollars per hour more than the minimum wage, in terms of job quality the work was basically as stressful and undignified as fast-food work. Hence it was logically consistent to state, as did the majority of my teammates, that the job "paid fair" yet they nonetheless "hated it."

\section{A Differentiated Class}

Given that workers quickly converged on their placement of CallCo on the bad job map, why did their subsequent strategies for navigating the job diverge? To address this puzzle, I contextualized each individual worker in relation to his or her biographical trajectory and material embeddedness. The result was a fourfold typology, summarized in Table 2. Also presented is modal demographic information for each category. Comparing categories in this way suggests that gender, race, and age intersected with class to produce specific experiences of call center work and subsequent navigation strategies.

Table 2 reveals that decisions to leave versus stay were gendered. On my first site visit to CallCo, I estimated that 90 percent of its workforce was female - a fact that I assumed was due to a gendered hiring process. But while my cohort was slightly skewed (thirteen of twenty-one, or 62 percent, were women), the extreme gendering of the labor force occurred subsequently, via the leaving process. Within nine months, every male worker had quit, while only five of the thirteen women had. One possible explanation is that the women were less troubled by the job than were the men. I feel confident ruling this out, however, as both the men and the women were initially "not happy campers," in Candy's words. A second possibility is the men were more likely to overestimate their chances on the labor market and thus risk unemployment (Ridgeway 1997). While my data do not 
allow me to measure workers' risk tolerance, they do suggest that men were more likely to risk exits because they exhibited different degrees of material embeddedness.

In brief, male call agents had fewer obligations and access to more resources than did female agents. As a result, their exits were less materially consequential. The trajectories of the Rebels (shown in Figure 3) illustrate this well. Prior to applying to CallCo, these individuals had been working minimum-wage "lifestyle" jobs. While they were not unhappy in these positions, they sought better-paying work to achieve financial independence. As the tedium of call center work wore them down, they indulged in cathartic - that is, unplanned-exits which thrust them directly into unemployment.

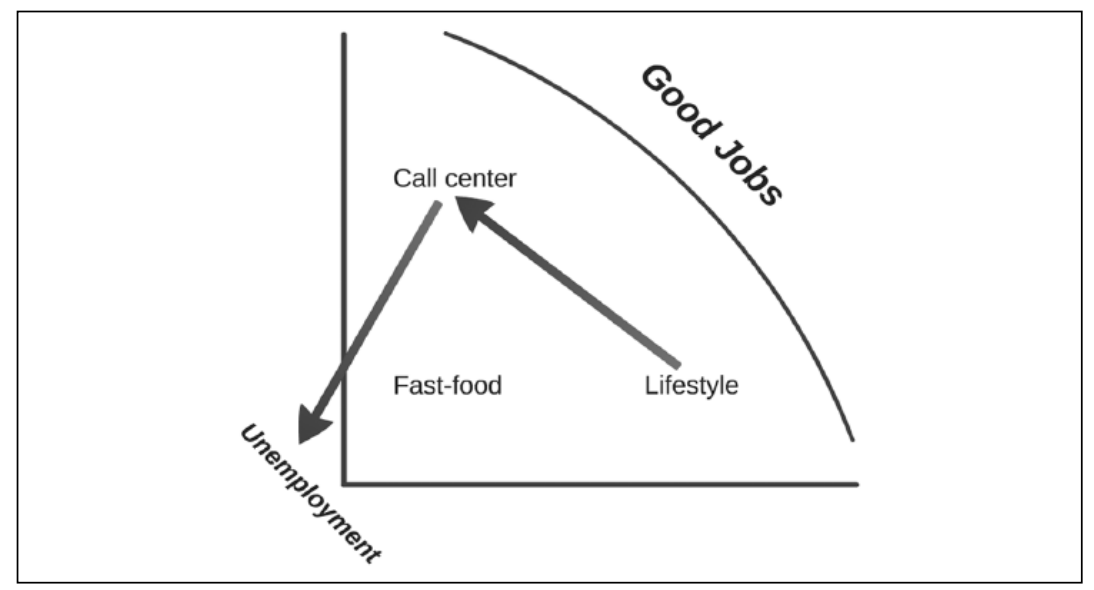

Figure 3. The Rebels' trajectory.

The Rebels, though now without wage income, were able to buffer themselves from immediate hardship. At the time of hire, only Ben materially supported a dependent (the girlfriend for whom he'd felt obligated to rent "a nice little house"). A few weeks before exiting CallCo, he'd ended this relationship, terminated his rental agreement, and commenced "couch-surfing." He also convinced his mother, a Wal-Mart worker, to give him a small monthly allowance "to buy cigarettes, to drink every now and then, whatever, just stuff like that." The other Rebels were similarly flexible in paring down their expenses and securing new resources. Eddie, right after reaching his eleventh point, moved out of his studio apartment and into his father's apartment, while Matt and Jill (the sole female Rebel) began cohabitating with 
long-term dating partners. Matt's girlfriend, a manager at a retail outlet, and Jill's boyfriend, the proprietor of a lawn-care business, supported their exits by allowing them to live rent-free.

The situation of the Breadwinners - young women with no nonwage resources and heavy obligations - was vastly different (Figure 4). They had applied to CallCo in search of better pay, mired as they had been in various minimum-wage jobs (ranging from retail to fast food). And while they too initially found call-work to be unpleasant, they learned to cope with it. Unlike the Rebels, they were providers who relied on CallCo's wage premium to keep their families out of poverty. A cathartic exit thrusting one directly into unemployment was unthinkable. But so too was the idea of returning to a minimum-wage job, insofar as this would entail a 32 percent drop in total household income, from around $\$ 21,000 /$ year to $\$ 15,000 /$ year. To put this in context, the official poverty threshold for a single worker with one dependent is $\$ 15,500$; for a mother of three children such as Alma, it is just under $\$ 21,000$. Thus, the marginal difference between a minimum (\$7.25) and a call center (\$11) wage represented, to the Breadwinners, a qualitative difference between (modest) prosperity and hardship. These women couldn't leave, and didn't.

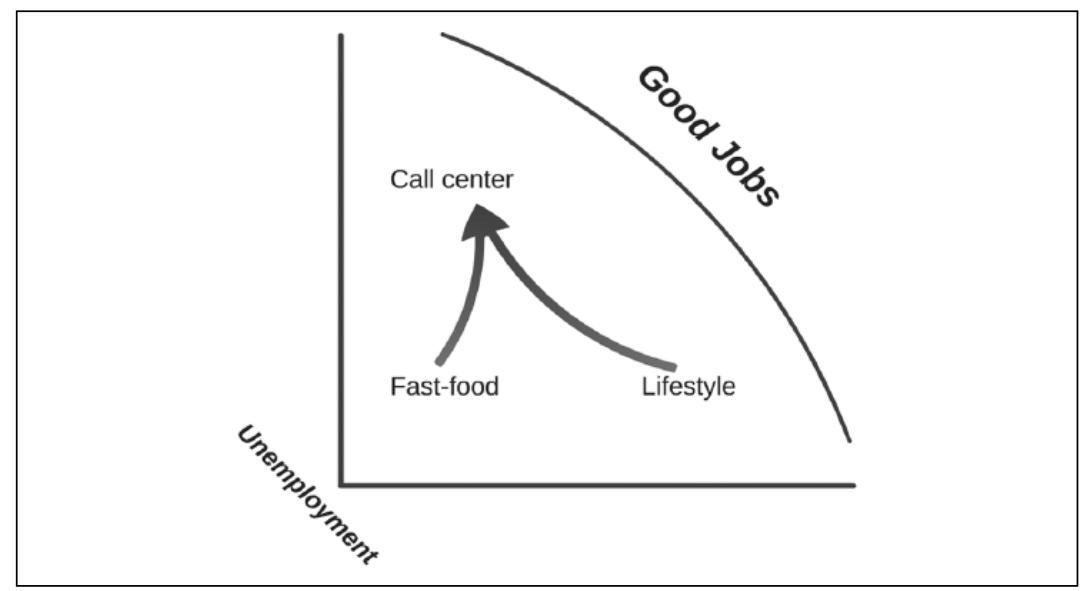

Figure 4. The Breadwinners' trajectory.

The Realists' trajectory (Figure 5) illustrates how race and gender intersect with class. Like the Breadwinners, the Realists were minority workers with dependents, and they too had long been working minimum-wage jobs. The difference was that the minority men were not sole providers. Each 
Realist had a relationship partner working at least part time in a minimumwage job. This meant that, immediately prior to obtaining employment at CallCo, their households had been grossing about $\$ 30,000$ annually $-\$ 9,000$ above the poverty line. Having one member of the household earn an $\$ 11$ wage had boosted this figure to around $\$ 36,000$. As each Realist experienced intense happiness with call center work, they could imagine exits that would not put their dependents at risk. As long as they lined up other employment in advance - that is, executed calculated exits - quitting CallCo would at worst drop total household earnings by $\$ 6,000$ per year. Considering how badly they hated the call center, this was a tolerable tradeoff.

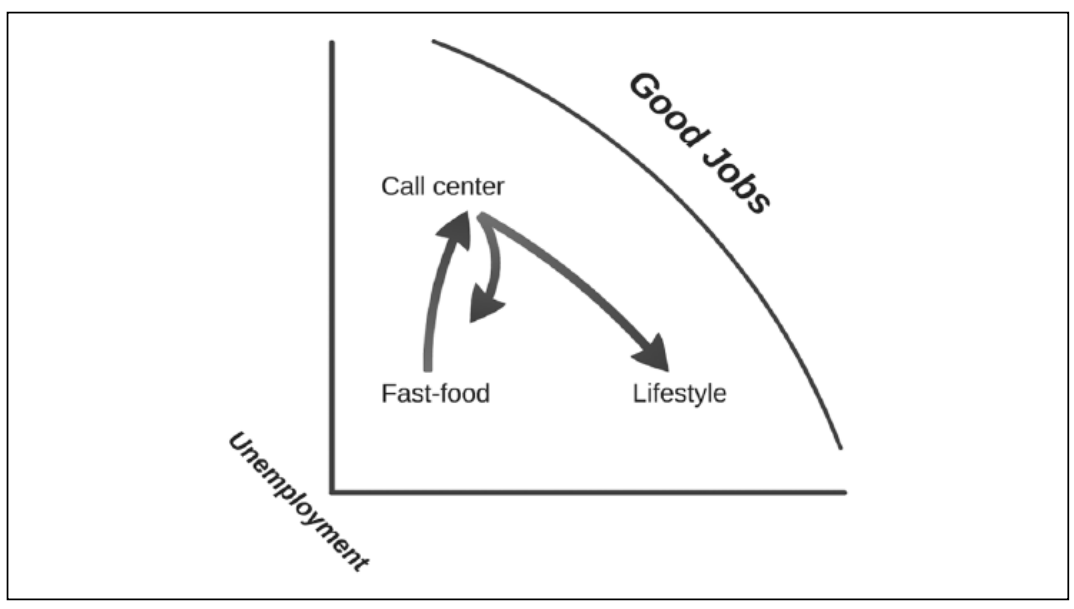

Figure 5. The Realists' trajectory.

Furthermore, the Realists strategically used call center work to improve their positioning in the bad job space. Tony and Camila obtained small raises in their existing jobs, while Jerome and Caleb moved from fast-food to retail jobs. But the opportunity to take such paths was available to them only because they could count on a working partner. This gendered difference in family structure among poor minorities has been extensively documented in the literature. For a variety of factors, such as the mass incarceration of minority men, minority women are more likely to find themselves as sole providers (Edin and Kefalas 2005; Woodward 2013). A contribution of this study has been to document the implications for how such individuals experience specific bad jobs.

Age too intersected with class to produce a distinct trajectory through the bad job space (Figure 6). Like the Breadwinners, the Resigned were women 
workers with no significant savings. Theirs was a downward trajectory, however, as they'd once achieved the American Dream of good jobs and working-class prosperity (the apogee of which is self-employment). This dream finally ended when the 2008 financial crisis ruined their small businesses and sent them back into the labor market. The post-Fordist landscape of bad jobs was new to them. Unable to regain a good job, excluded because of their age from the "lifestyle" sector, and with the specter of fast food work looming, CallCo was essentially a life-preserver. But it was also a test of endurance.

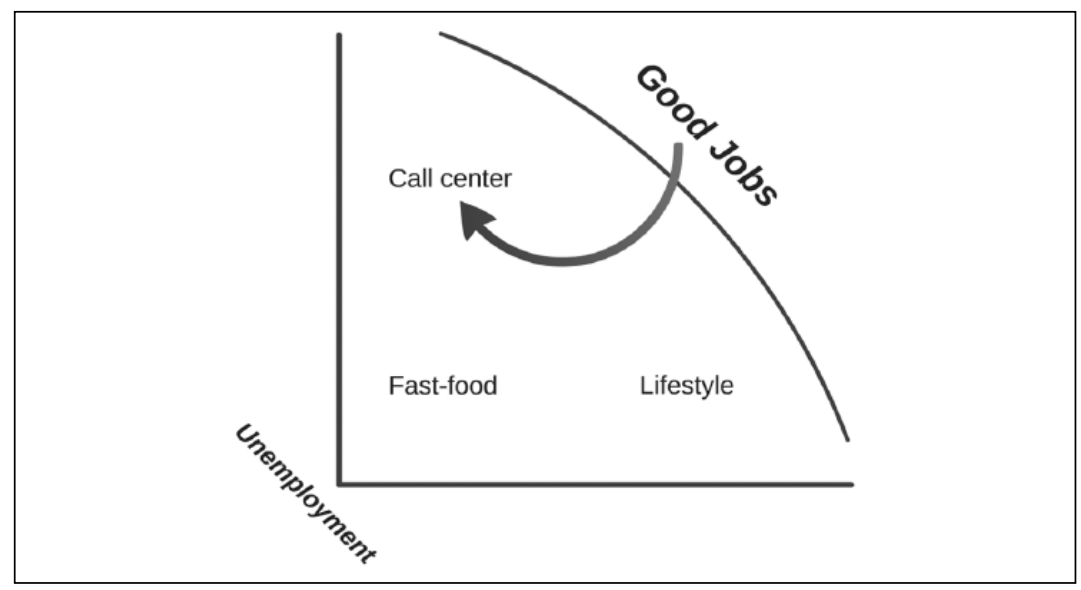

Figure 6. The Resigned trajectory.

Of all my teammates, these older workers struggled most to square their experiences and expectations with the reality of call center work. Months into the job, for instance, they complained openly about the lack of health benefits and regular raises. Younger workers would roll their eyes and make snide remarks about their "dinosaur" (in Sophia's words) teammates. Yet because of their age and prior employment histories, the Resigned were the only workers who could anticipate using material support from the state to permanently exit the landscape of bad jobs. They had a tangible exit plan: Social Security benefits, which one can claim as early as age sixty-three and after which the Resigned planned to cease working or at least reduce their hours. For precarious older workers, an otherwise bad job can serve as a bridge between an honorable life and a decent retirement.

Twenty-one workers entered a call center, and only eight stayed. The various strategies documented herein for navigating the call center establish that precarious workers - even in a post-Fordist, postwelfare era - can exercise agency. But I've also demonstrated that the form such agency takes depends 
upon one's personal biography and material embeddedness: abductive concepts that overlap significantly with gender, race, and age. The experiences of a single cohort of call center workers suggest how class intersects with other principles of division to shape decisions to leave versus stay in a given bad job. But I have also situated this particular bad job within the larger bad job space. The calculi by which workers navigate specific bad jobs will depend upon their larger trajectories through this emergent landscape.

\section{Declaration of Conflicting Interests}

The author(s) declared no potential conflicts of interest with respect to the research, authorship, and/or publication of this article.

\section{Funding}

The author(s) disclosed receipt of the following financial support for the research, authorship, and/or publication of this article: The author received support for this research via a grant from the University of Arizona Social and Behavioral Sciences Research Institute (Grant \#13RPF0188).

\section{Notes}

1. All organizations and individuals have been given pseudonyms.

2. See Sallaz (2015).

3. Available at http://www.icpsr.umich.edu/icpsrweb/DSDR/studies/3979.

4. That my scheme is not exhaustive is suggested by the five workers who did not fit into these four categories. Paige and Bree, the two workers on the far left of Figure 1, quit just a few days into training. Both were women in their thirties who had recently relocated to accommodate working partners. Neither had children or dependents, and both had applied to the call center as a way to deal with loneliness and boredom. But both exhibited immediate and intense physical reactions to the job. Paige, for instance, spoke ruefully of having given up a "government job" back east, and claimed not to be sleeping because of anxiety attacks. After the third day of training, she never showed up again. The three workers on the lower right in turn persisted for quite some time, but in the end each possessed an idiosyncratic trait that left him or her unable to cope with call center work. For instance, Julie, fifty-eight years old and recently downsized from a clerical position, breezed through training. On the production floor, however, she was confronted with irate callers who repeatedly cursed at her. This bothered Julie, a deeply religious woman, immensely: "I'm trying to get them to understand how the system works. And they would tell me, 'You are the most stupidest person in the world. F you. F you. F you.' Lots of F yous." Julie cited these repeated violations of her moral code as the reason she quit.

\section{References}

Abramson, Corey M. 2015. The End Game: How Inequality Shapes Our Final Years. Cambridge, MA: Harvard University Press. 
Bain, Peter, and Phil Taylor. 2000. "Entrapped by the 'Electronic Panopticon'? Worker Resistance in the Call Centre." New Technology, Work and Employment 15 (1): 2-18.

Bourdieu, Pierre. 2000. Pascalian Meditations. Translated by Richard Nice. Stanford, CA: Stanford University Press.

Boushey, Heather. 2005. "No Way Out: How Prime-Age Workers Get Trapped in Minimum-Wage Jobs.” WorkingUSA 8 (6): 659-70.

Collins, Jane L., and Victoria Mayer. 2010. Both Hands Tied: Welfare Reform and the Race to the Bottom in the Low-Wage Labor Market. Chicago: University of Chicago Press.

Cromdal, Jakob, Karin Osvaldsson, and Daniel Persson-Thunqvist. 2008. "Context That Matters: Producing 'Thick-Enough Descriptions' in Initial Emergency Reports.” Journal of Pragmatics 40 (5): 927-59.

Desmond, Matthew. 2012. "Disposable Ties and the Urban Poor." American Journal of Sociology 117 (5): 1295-1335.

Edin, Kathryn, and Maria J. Kefalas. 2005. Promises I Can Keep: Why Poor Women Put Motherhood before Marriage. Berkeley: University of California Press.

Edin, Kathryn, and Laura Lein. 1997. Making Ends Meet: How Single Mothers Survive Welfare and Low-Wage Work. New York: Russell Sage Foundation.

Fink, Deborah. 1998. Cutting into the Meatpacking Line: Workers and Change in the Rural Midwest. Chapel Hill: University of North Carolina Press.

Goffman, Alice. 2009. “On the Run: Wanted Men in a Philadelphia Ghetto.” American Sociological Review 74 (3): 339-57.

Halpern-Meekin, Sarah, Kathryn Edin, Laura Tach, and Jennifer Sykes. 2015. It's Not Like I'm Poor: How Working Families Make Ends Meet in a Post-welfare World. Berkeley: University of California Press.

Hodson, Randy. 2001. Dignity at Work. New York: Cambridge University Press.

Kalleberg, Arne L. 2013. Good Jobs, Bad Jobs. New York: Russell Sage Foundation. Katz, Jack. 1988. Seductions of Crime. New York: Basic Books.

Maanen, John Van, Jesper B. Sørensen, and Terence R. Mitchell. 2007. "The Interplay between Theory and Method." The Academy of Management Review 32 (4): 1145-54.

Mears, Ashley, and William Finlay. 2005. "Not Just a Paper Doll." Journal of Contemporary Ethnography 34 (3): 317-43.

Milkman, Ruth. 1997. Farewell to the Factory. Berkeley: University of California Press.

Newman, Katherine S. 2000. No Shame in My Game: The Working Poor in the Inner City. New York: Vintage.

Ong, Beng Kok. 2012. "Grounded Theory Method (GTM) and the Abductive Research Strategy (ARS).” International Journal of Social Research Methodology 15 (2): 417-32.

Pager, Devah, and Hana Shepherd. 2008. "The Sociology of Discrimination: Racial Discrimination in Employment, Housing, Credit, and Consumer Markets." Annual Review of Sociology 34 (1): 181-209. 
Pedulla, David S. 2013. "The Hidden Costs of Contingency." Social Forces 92 (2): 691-722.

Piore, Michael J., and Sean Safford. 2006. "Changing Regimes of Workplace Governance, Shifting Axes of Social Mobilization, and the Challenge to Industrial Relations Theory." Industrial Relations: A Journal of Economy and Society 45 (3): 299-325.

Putnam, Robert D. 2015. Our Kids: The American Dream in Crisis. New York: Simon \& Schuster.

Ridgeway, Cecilia L. 1997. "Interaction and the Conservation of Gender Inequality: Considering Employment.” American Sociological Review 62 (2): 218-35.

Sallaz, Jeffrey J. 2015. "Permanent Pedagogy: How Post-Fordist Firms Manufacture Effort but not Consent." Work and Occupations 42 (1): 3-34.

Sharone, Ofer. 2013. Flawed System/Flawed Self. Chicago: University of Chicago Press.

Silva, Jennifer M. 2012. "Constructing Adulthood in an Age of Uncertainty." American Sociological Review 77 (4): 505-22.

Smith, Sandra Susan. 2005. “'Don't Put My Name on It': Social Capital Activation and Job-Finding Assistance among the Black Urban Poor." American Journal of Sociology 111 (1): 1-57.

Standing, Guy. 2014. The Precariat: The New Dangerous Class. Reprint edition. London: Bloomsbury Academic.

Timmermans, Stefan, and Iddo Tavory. 2012. "Theory Construction in Qualitative Research from Grounded Theory to Abductive Analysis." Sociological Theory 30 (3): 167-86.

Tomlinson, Mark, and Robert Walker. 2012. "Labor Market Disadvantage and the Experience of Recurrent Poverty." In The Age of Dualization, edited by Patrick Emmenegger, 52-72. New York: Oxford University Press.

Venkatesh, Sudhir. 2009. Off the Books: The Underground Economy of the Urban Poor. Cambridge, MA: Harvard University Press.

Watson, Tony James, and Diane Heather Watson. 2012. "Narratives in Society, Organizations and Individual Identities." Human Relations 65 (6): 683-704.

Williams, Christine L., and Catherine Connell. 2010. "“Looking Good and Sounding Right': Aesthetic Labor and Social Inequality in the Retail Industry." Work and Occupations 37 (3): 349-77.

Woodward, Kerry. 2013. “'Pimping the System': How Economic, Social, and Cultural Capital Are Deployed in a Welfare Program." Journal of Contemporary Ethnography 43 (1): 3-37.

Wright, Sharon. 2012. "Welfare-to-Work, Agency and Personal Responsibility." Journal of Social Policy 41 (2): 309-28.

\section{Author Biography}

Jeffrey J. Sallaz is an associate professor at the University of Arizona's School of Sociology. His participant observation studies have included stints as a call center agent, a corporate marketer, and a casino croupier. Currently he is working on a book about the call center industry in the Philippines. 